\title{
MAJOR LANDSLIDES STABILIZATION ON ORĂŞTIE-SIBIU MOTORWAY
}

Anton Chirică, Prof. PhD. Eng., Technical University of Civil Engineering Bucharest, antonchirica@yahoo.com;

Andrea Danese, Sales Manager, Astaldi S.p.A., Rome, Italy, a.danese@astaldi.com;

Rosario Russo, Eng., Italrom Inginerie Internationala S.R.L., Bucharest, Romania, r.russo@italrominginerie.com;

Lorenzo Sabini, Eng., Italrom Inginerie Internationala S.R.L., Bucharest, Romania, l.sabini@italrominginerie.com.

\section{Rezumat}

Lucrarea prezintă strategia complexă utilizată pentru stabilizarea unei alunecări majore de teren produse în timpul unei lucrări de remodelare a unui deal pe traseul autostrăzii Orăştie-Sibiu. Litologia locală, împreună cu influenţa schimbării stării de eforturi şi comportamentul special al argilelor structurate, au condus la proiectarea şi implementarea unor măsuri de stabilizare din partea constructorului "Astaldi".

Se prezintă câteva investigaţii suplimentare in-situ şi de laborator, precum şi principalele tipuri de lucrări care au condus la stabilizarea taluzului, analizate atât în condiţii statice, cât şi dinamice.

Cuvinte cheie: alunecări de teren, stabilizare taluz, monitorizare, argilă de Sibiu, tehnologii integrate

\section{Abstract}

The paper presents the complex strategy used to stabilize a major landslide started during a hill shaping along the Orăştie-Sibiu motorway. Local lithology, together with the influence of the change of the stress state and the particular behavior of structured clays, led to the design and implementation on the part of the contractor "Astaldi" of stabilization measures.

Some additional in-situ and laboratory investigations are presented, as long as the main type of works that led to slope stability, analyzed in both static and dynamic conditions.

Keywords: landslides, slope stabilization, monitoring, Sibiu clay, integrated technologies 


\section{INTRODUCTION}

During the execution of the Orăştie-Sibiu motorway, the side slopes of the design route have been affected by several landslides and instability phenomena of various entity. Besides them, most ancient episodes were observed along several fronts facing the roadway. Such events highlighted a general condition quite difficult concerning the stability condition. A clear evidence of such condition is represented by the section between $\mathrm{km} 73+735$ and $\mathrm{km} 74+020$, along which the construction of the road layout was conditional on the fulfillment of radical interventions.

\section{SITE DESCRIPTION}

The Orăştie-Sibiu lot 4 route starts from $\mathrm{km} 65+965$ and arrives to the DJ 106B roundabout of Sibiu. In the area $73+673.50$ and $74+016.80$, with a length of $340 \mathrm{~m}$, it interacts with the slope of a hill. It belongs to the Southern edge of the hilly area of the Transylvanian depression, which has several geomorphological processes. This area is about $500 \mathrm{~m}$ above sea level, surrounded on all sides except the North-Western region of the hills and mountains. The area was divided by a number of streams, rivers to form a rolling terrain with alluvial plains on valley bottoms. The hills are modeled on balances or for washing the surface water runoff; the hillsides and valleys highlight the shallow landslides along with a very active torrent. Depressions contact with the extended strip mount is characterized by the accumulation of droppings is in the form of cones or aprons. Hilly valleys are wide meadows units, alluvial in flood with active bank erosion usually placed asymmetrically.

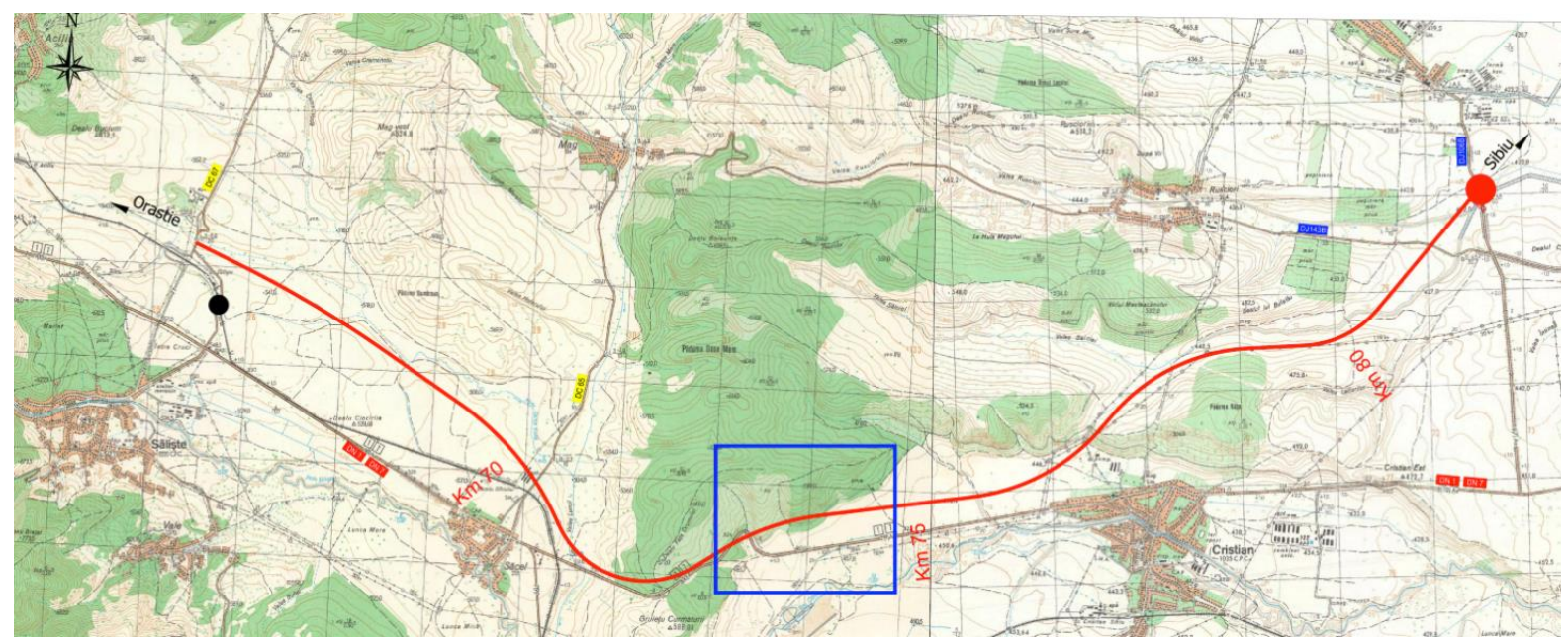

Figure 1. Motorway Orăştie-Sibiu Lot 4 route and area of intervention 
Between motorway $\mathrm{km} 73+735$ and $\mathrm{km} 74+020$ the design route requests a sensitive reshape of the side slope of a hill (Figure 2). The elevation of the hill is about $580.0 \mathrm{~m}$ above sea level, and about $90.0 \mathrm{~m}$ above the design level of the motorway. The highest slope has a North-West to South-West direction and it can be taken perpendicular to the motorway axis. The hill is characterized by a dense shrub vegetation, especially in the upper part where the area becomes forested.

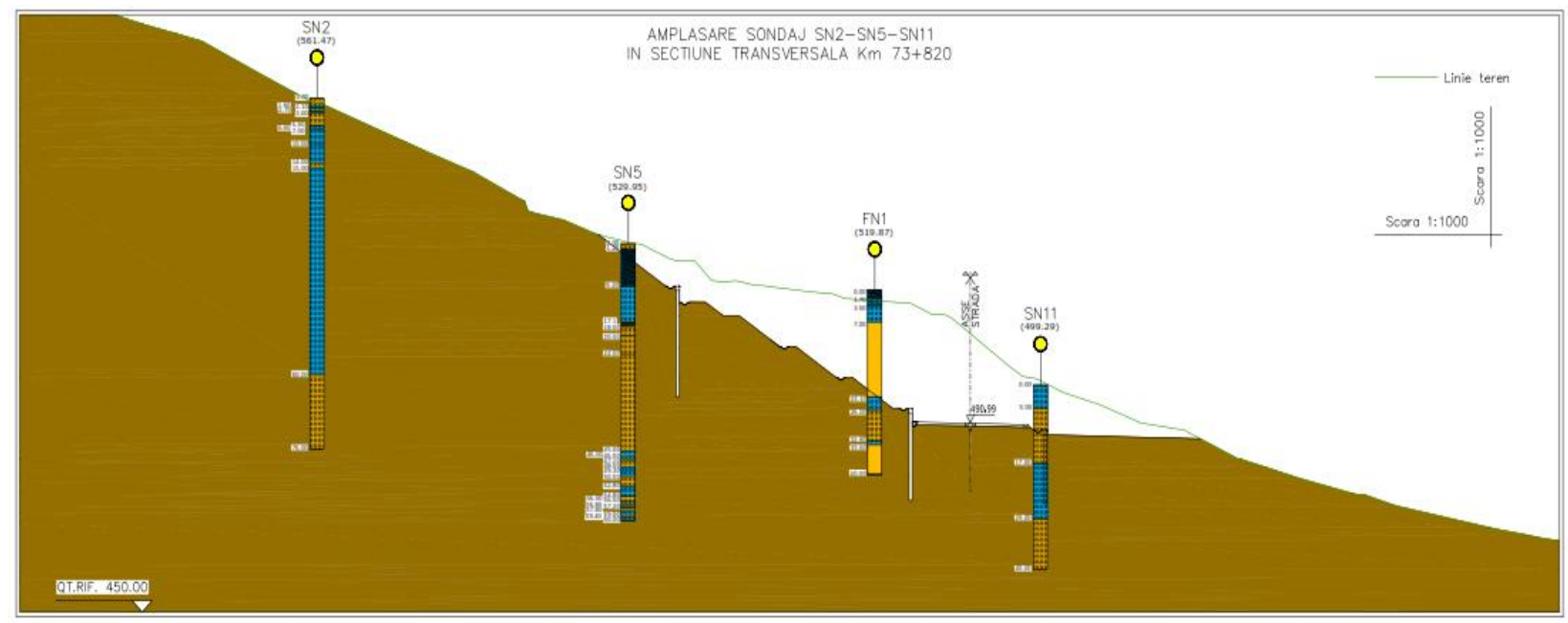

Figure 2. Example of design section at $\mathrm{km} 73+820$

Instability phenomena observed are characterised by the following general facts:

0 these are slidings of delapsiv type (regresive) as the displacement line (front) of unstable soil volume moves to the top of the slope;

O considering the displacement speed, these are very slow landslides, meaning that speeds of some centimeters/year are to be found;

0 these are consistent landslides as probable landslide surfaces present slopes in the same direction of the interface between lithological formations;

O these are „deep" landslides as the depth of probable surfaces for landslides is higher than $5.00 \mathrm{~m}$.

The phenomena object of the study are represented by two landslides of different ages (Figure 3): the first, in correspondence of $\mathrm{km} 73+640$ and $\mathrm{km}$ $73+900$ is an ancient movement, steady to date; the second one is represented by a new activity started in March 2012, between $\mathrm{km} \mathrm{73+900} \mathrm{and} \mathrm{km} \mathrm{74+100.} \mathrm{The}$ 
next phases of excavation and remodeling of the slope had to be analyzed and verified in terms of stability for both of them.

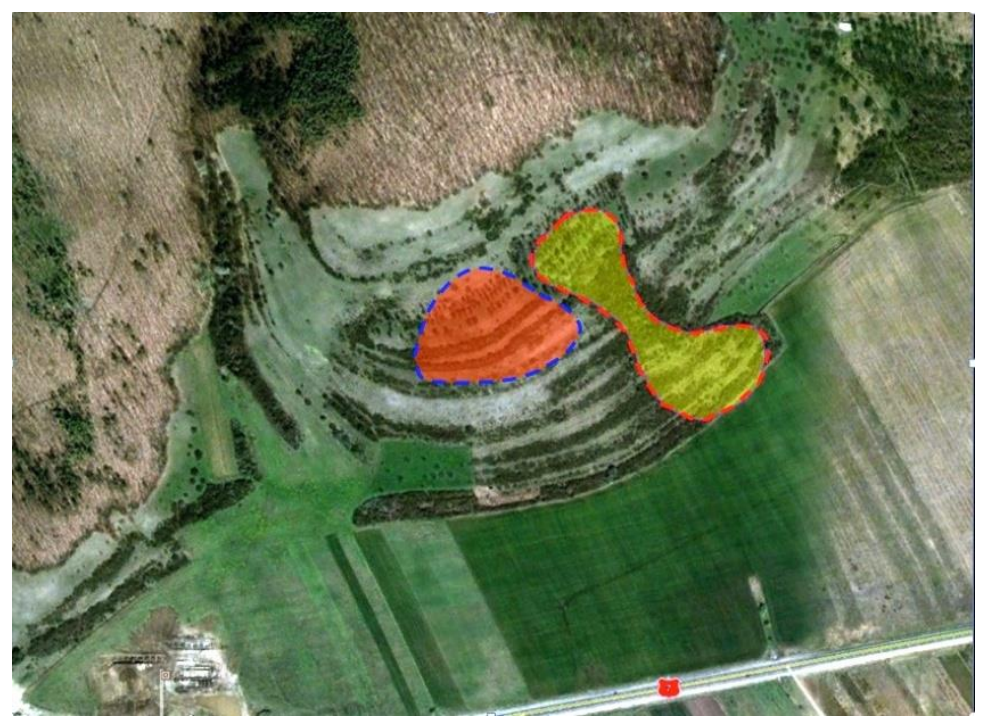

Figure 3. Plan view of the area and landslides plan shapes

\section{GENERAL GEOLOGICAL AND SEISMIC CONDITIONS}

The geology of the area is characterized by the Neogene Panoniane era (Figure 4). Transylvania southern Pannonian depression consists of two complexes:

- A clay marls complex, which thickens to the NE with sandy clay in the upper part;

- An upper debris complex, with yellowish friable sandstone and gravel elements with white quartz, and quartz sands with shingle soft marl and clay intercalations of reddish or yellowish grey.

Under the Panonian formation, the Sarmatian deposits are found (Volhinian-Bessarabian vh-bs) represented by the grey marl and sandy marl containing fossil of Cardium and Trochus. The level below is the "bugloviene" (bg) marley clay, sand with Ervilia: this formation appears to the surface many times. Quaternary is represented in the upper part of the Holocene deposits, consisting of clay, silty clay, and sandy clay with rare gravel largely of alluvial origin. It is to be noted that the design route is spread along the contact zone between the recent sedimentary and the ancient metamorphic crystalline formations (Epimetamorphic Sebes series). 
ROMANIAN JOURNAL

OF TRANSPORT INFRASTRUCTURE

Anton Chirică, Andrea Danese, Rosario Russo, Lorenzo Sabini

Major landslides stabilization on Orăştie-Sibiu motorway

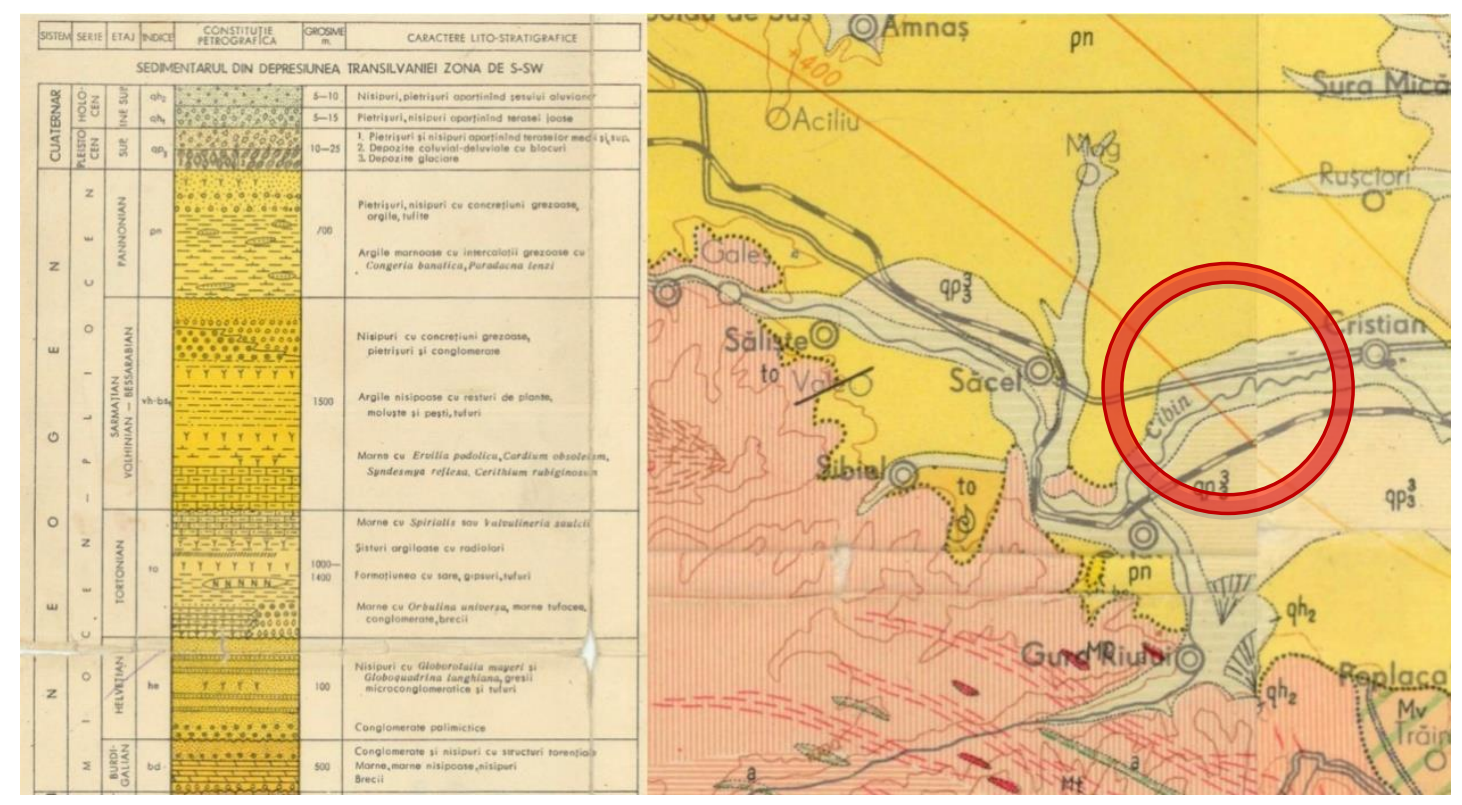

Figure 4. Extract of the geological map of the area

From a geomorphological point of view, the area is located in a zone of tectonic depression synclines presenting a proluvio-alluvial aspect; the landscape is typical of a depression with hilly and lowland aspect, agricultural land, meadows and forests of beech and hornbeam and oak. According to P1001/2006 Norm, from a seismical point of view, for earthquakes having a medium recurrence period, IMR $=100$ years, peak value of horizontal acceleration is $\mathrm{a}_{\mathrm{g}}=$ $0,16 \mathrm{~g}$ and peak value for vertical acceleration is $\mathrm{a}_{\mathrm{vg}}=0,7 \mathrm{ag}_{\mathrm{g}}$; value of the control period for the response spectrum is $\mathrm{T}_{\mathrm{c}}=0,7$ seconds.

\subsection{Integrative geognostic survey results}

In order to characterize the instabilities observed along the slope and to define the parameters needed for sizing of the interventions, an extensive campaign of geognostic investigations has been performed by the contractor Astaldi as follows (Figure 5):

- 17 boreholes, lengths $20.0 \mathrm{~m}-76.0 \mathrm{~m}$;

- 160 standard penetration test (SPT) along boreholes, with a $3.0 \mathrm{~m}$ step;

- 3 cone penetration tests (CPT);

- 11 inclinometers in the boreholes;

- 8 geo-electric profile by tomographic display;

- 8 seismic profiles by tomographic display;

- laboratory test on samples from the boreholes 


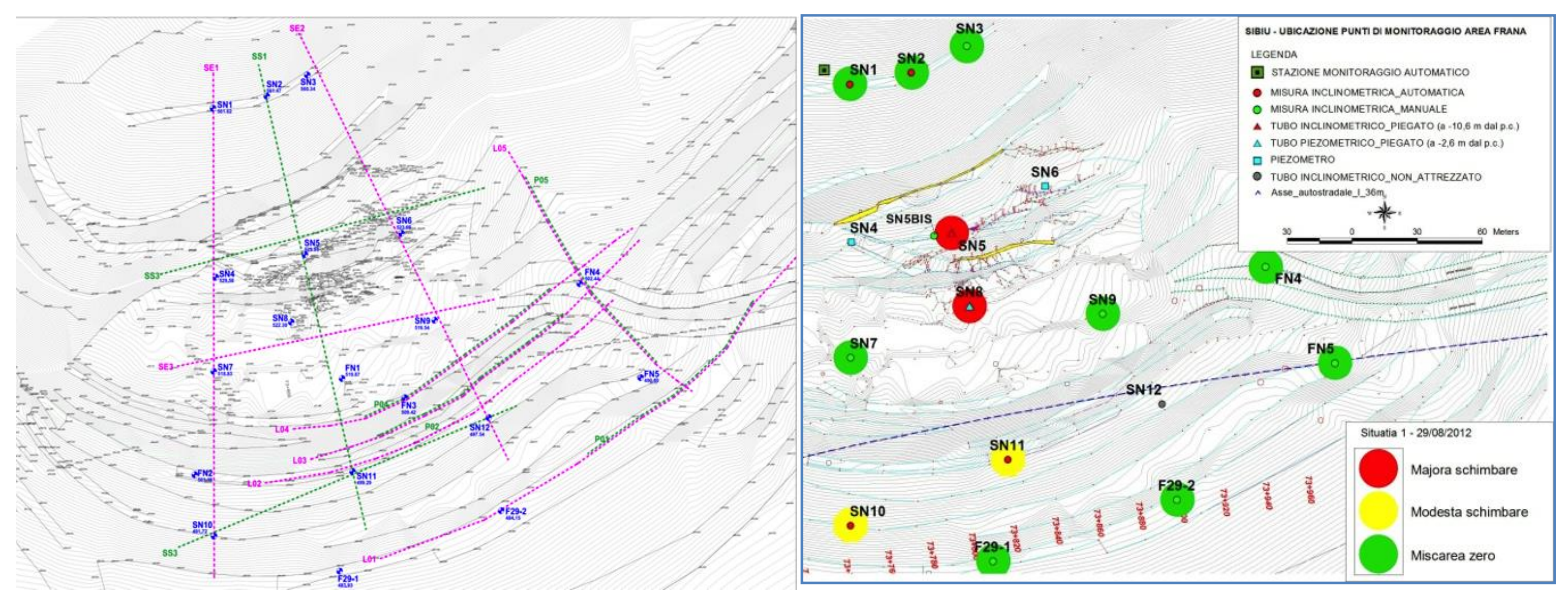

Figure 5. Left: Boreholes, geophysical test and inclinometers network installed in the area

To date, after the end of works, the inclonometric network is still working for the control of the new design section and feedback of the interventions realized.

\subsection{Lithology}

The analyses of stratigraphic columns performed have shown a strong inhomogeneity of the soils, whose covering formation has been characterized as follows:

- Clay, silty clay and sandy clay:

○ Humidity $\mathrm{w}=(12.80 \div 30.5) \%$;

○ Plasticity Index $\mathrm{I}_{\mathrm{p}}=(14.10 \div 34.0) \%$;

$\circ$ Unit weight $\gamma=(18.25 \div 20.94) \mathrm{kN} / \mathrm{m}^{3}$;

○ Pores Index e $=0.43 \div 0.85$.

- Sand, Silty sand and clayey sand:

○ Humidity $\mathrm{w}=(16.0 \div 16.5) \%$;

$\circ$ Unit weight $\gamma=(15.0 \div 21.0) \mathrm{kN} / \mathrm{m}^{3}$;

○ Pores Index e $=0.46 \div 0.85$.

Referring to the instability observed, the geognostic surveys have made clear a 10.0-12.0 m depth sliding surface in the area between $\mathrm{km} 73+640$ and $\mathrm{km}$ $73+900$ and a second 5.0-6.0 m depth sliding surface in the area between $\mathrm{km}$ $73+900$ and $\mathrm{km} \mathrm{74+100.}$ 


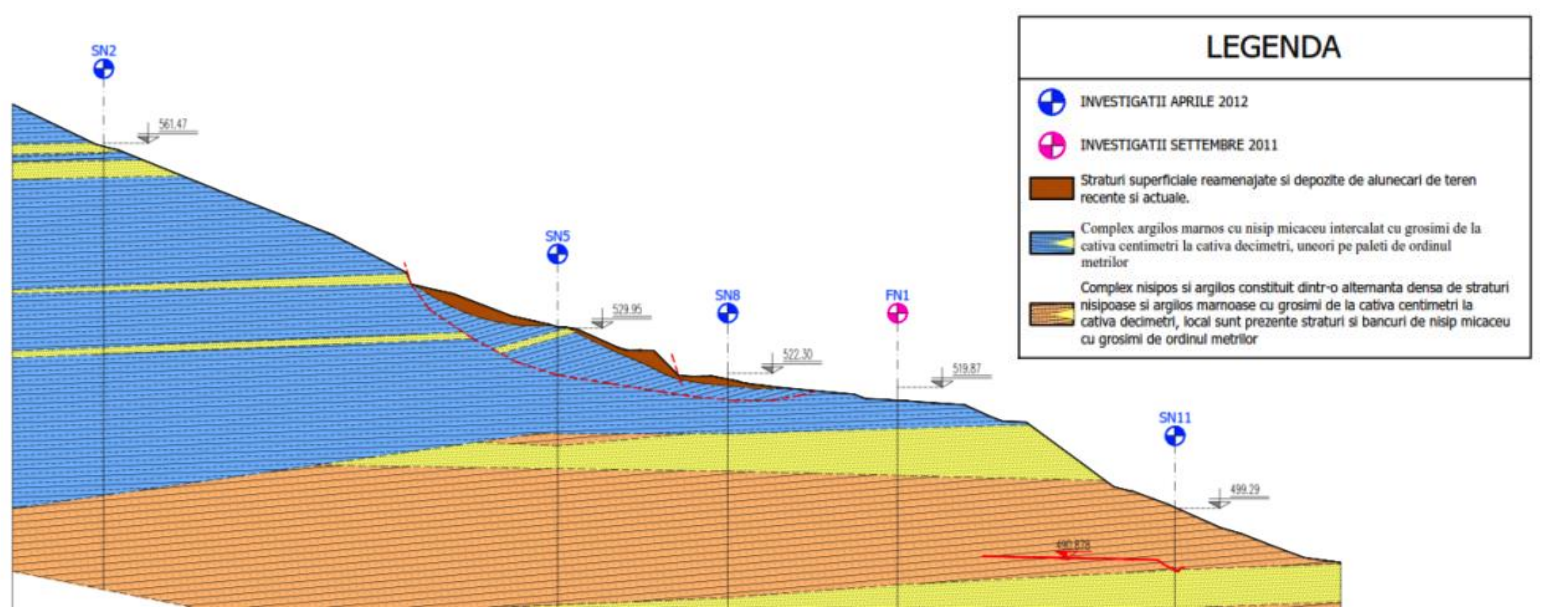

Figure 6. Stratigraphic section example of the slope at km 74+000

\subsection{Geophysical surveys}

Moreover, seismic and geoelectric profiles have shown a possible sliding surface inside the covering formation between marley clay and the underlaying layer, with a depth of 10-15 m next to the motorway route.
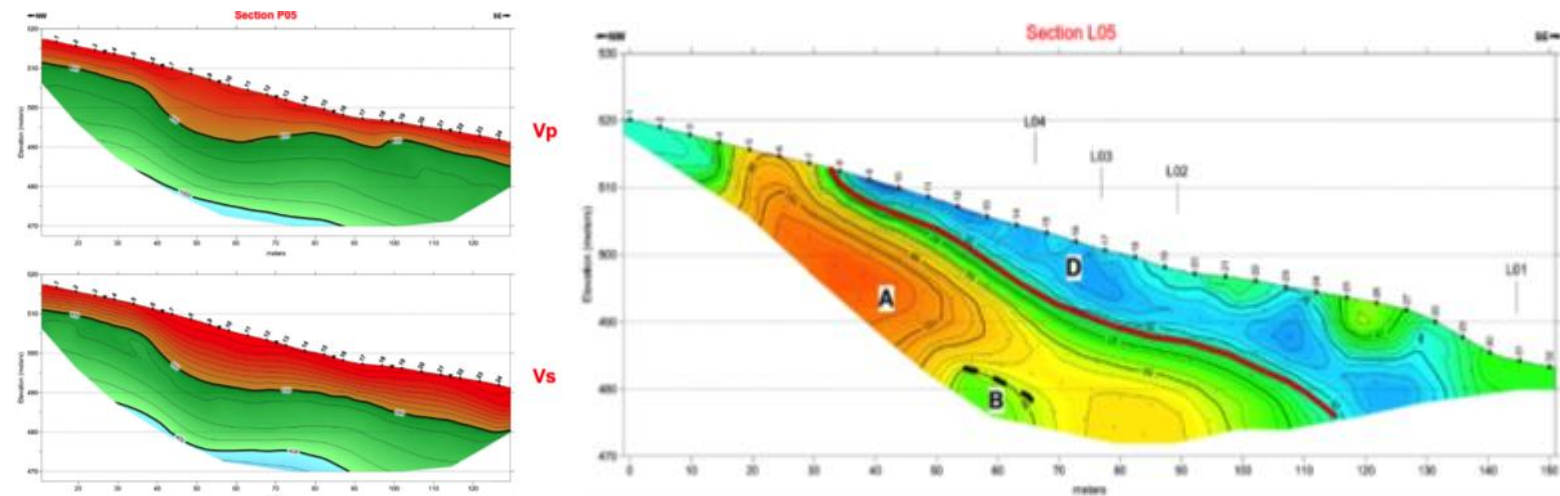

Figure 7. Geophysical test results samples (seismic on the left, geoelectric on the right)

\subsection{Analysis parameters}

For the area between $\mathrm{km} 73+673.5$ and $\mathrm{km} 73+945$, the analysis parameters have been defined as follows:

- Upper Layer "Clay, silty clay and sandy clay":

$\circ \gamma=19.5 \mathrm{kN} / \mathrm{m}^{3}$;

$\circ \varphi=25.0^{\circ}$;

○ $\mathrm{c}^{\prime}=30.0 \mathrm{kPa}$.

- Lower layer "Sand, silty sand and clayey sand": 
○ $\gamma=19.5 \mathrm{kN} / \mathrm{m}^{3}$

$\circ \varphi=32.0^{\circ}$;

$\circ \mathrm{c}^{\prime}=0.0 \mathrm{kPa}$

For the area between $\mathrm{km} 73+945$ and $\mathrm{km} 74+016$, the analysis parameters have been defined as follows:

- Upper Layer "Upper silty clay":

○ $\gamma=19.5 \mathrm{kN} / \mathrm{m}^{3}$;

$\circ \varphi=21.0^{\circ}$;

$\circ \quad \mathrm{c}^{\prime}=12.0 \mathrm{kPa}$.

- Lower Layer "Lower silty clay":

○ $\gamma=19.5 \mathrm{kN} / \mathrm{m}^{3}$;

○ $\varphi=25.0^{\circ}$;

$\circ \quad \mathrm{c}^{\prime}=18.0 \mathrm{kPa}$.

\section{LANDSLIDE EVOLUTION AND TRIGGER MECHANISM}

\subsection{Causes}

As noted above, the llithology of the area is generally made of clay silts/sandy, brown and grey silty clays and hard plastic marley clays with high plasticity, with varying degrees of alteration and fracturing; moreover, sand lenses create inhomogeneities in terms of shear strength parameters, in particular. Sibiu structured clays are characterized by a specific macrostructure which gives them a pronounced sensitivity to wetting under shear stress; through the mechanism described, by excavating and in the presence of free water sources, in such clays, shear strength decreases to residual values leading to the onset of progressive landslide. As established by Karl Terzaghi (1936), for this type of clays, displacements by shearing lead to relative movements between aggregates along the cracks and their opening. Because of this feature, structured clays are characterized by the presence of aggregates of different shapes and sizes, yields to the shear, inside the areas where locally, their strength decreases and not where the tangential effort is the highest.

\subsection{Static and dynamic stability analysis}

The general stability conditions of the slope are poor, as seen in the early stages of execution. Thus made the design of widespread consolidation interventions necessary. Moreover, by taking into account the behavior of Sibiu 
clays, not only a local solution has to be studied, but a multiple purpose set of interventions in order to achieve the following:

- increasing the global shear resistance of the slope;

- obtaining an effective drainage and control system of the ground water;

- protecting the slope surface by weather agents such as erosion.

Starting from current conditions of stability and section type compatible with the road design, it has been developed a wide range of limit equilibrium analyses according to most solutions (Fellenius, Bishop, Bell, MorgenstenPrices, Spencer, Sarma). After this, once defined the effect of interventions on the stability of the slope, it has been proceeded to the analysis of structural design of the interventions. In detail, the analyses have been performed among two Ultimate Limit States: the geotechnical and the seismic one, respectively (pseudostatic approach). The analyses have been performed with approach 1 by Eurocodes frame and national Romanian annex, involving the partial safety factor parameters described in Tables 1 and 2 .

Table 1. Action safety factors by SR 1997

\begin{tabular}{|c|c|c|c|c|c|c|c|c|}
\hline \multirow{2}{*}{ Load } & \multirow{2}{*}{ Effect } & & \multicolumn{3}{|c|}{ Static } & \multicolumn{3}{c|}{ Seismic } \\
\cline { 4 - 9 } & & & EQU & $\mathrm{A} 1$ & $\mathrm{~A} 2$ & $\mathrm{EQU}$ & $\mathrm{A} 1$ & $\mathrm{~A} 2$ \\
\hline Permanent & Favorable & $\gamma_{\text {Gfav }}$ & 0.90 & 1.00 & 1.00 & 1.00 & 1.00 & 1.00 \\
\hline Permanent & Unfavorable & $\gamma_{\text {Gsfav }}$ & 1.10 & 1.35 & 1.00 & 1.00 & 1.00 & 1.00 \\
\hline Variable & Favorable & $\gamma_{\text {Gfav }}$ & 0.00 & 0.00 & 0.00 & 0.00 & 0.00 & 0.00 \\
\hline Variable & Unfavorable & $\gamma_{\text {Gsfav }}$ & 1.50 & 1.50 & 1.30 & 1.00 & 1.00 & 1.00 \\
\hline
\end{tabular}

Table 2. Geotechnical parameters safety factors by SR 1997

\begin{tabular}{|l|c|cc|c|c|}
\hline \multirow{2}{*}{ Parameter } & \multicolumn{3}{c|}{ Static } & \multicolumn{2}{c|}{ Seismic } \\
\cline { 3 - 7 } & & M1 & M2 & M1 & M2 \\
\hline Friction angle $(\tan )$ & $\gamma_{\text {tan } \square \text { a }}$ & 1.00 & 1.25 & 1.00 & 1.25 \\
\hline Cohesion & $\gamma_{\mathrm{c}^{\prime}}$ & 1.00 & 1.25 & 1.00 & 1.25 \\
\hline Undrained resistance & $\gamma_{\mathrm{cu}}$ & 1.00 & 1.40 & 1.00 & 1.40 \\
\hline Uniaxial compressive strength & $\gamma_{\mathrm{qu}}$ & 1.00 & 1.60 & 1.00 & 1.60 \\
\hline Weight per volume & $\gamma_{\square}$ & 1.00 & 1.00 & 1.00 & 1.00 \\
\hline
\end{tabular}

\section{STABILIZATION WORKS}

\subsection{Earth thrust evaluation}

In order to define the kind of interventions and position along the slope, the first step of analysis refers to the evaluation of earth-thrust that they must be capable to support or, in other words, the improvement of shear resistance they 
have to offer. In detail, the analysis has been performed considering the stripes method, as follows:

$$
E_{i}=\sum_{1}^{i} G_{j} \sin \alpha_{j} \cos \alpha_{j}-\operatorname{tg} \phi_{r e z} \sum_{1}^{i} G_{j} \cos ^{2} \alpha_{j}
$$

where: $E_{i}=$ earth-thrust at i-th stripe;

$G_{i}=$ weight of the i-stripe;

$\alpha_{i}=$ critical surface slope at i-stripe base;

$\phi_{r e z}=$ residual friction angle.

This kind of approach allows to define the "resistance" that the structures shall bring to the slope, moreover defines their position along the slope. In the hypothesis of interventions downstream and upstream of the motorway, the evaluated thrusts are equal to $1800 \mathrm{kN} / \mathrm{m}$ and $3200 \mathrm{kN} / \mathrm{m}$, respectively. These results clearly show the need for the structural interventions described below. Furthermore, the next step of analysis is the global model of the new design slope, with interventions (local and widespread), in ULS seismic and geotechnical, with surcharges as described in the previous chapter (Figure 8).

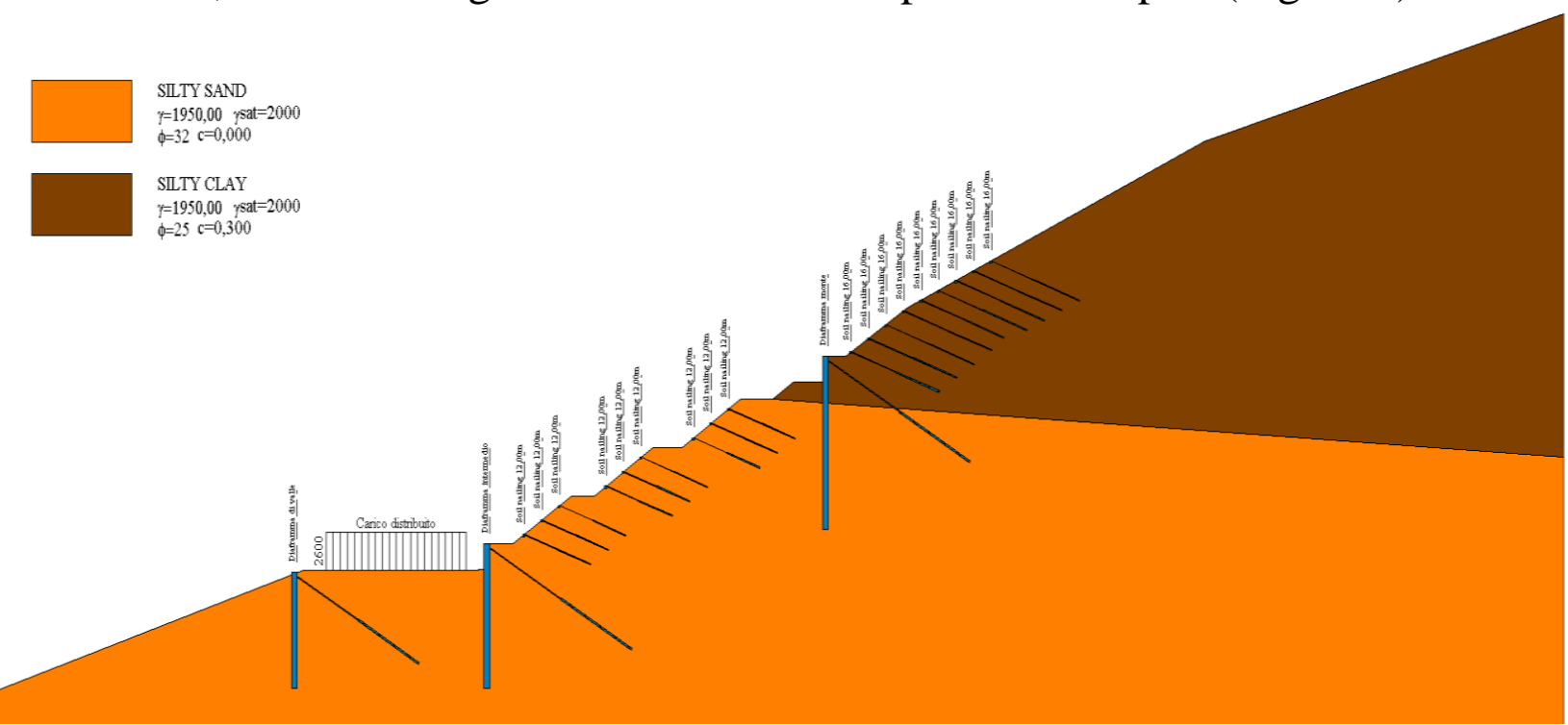

Figure 8. Global model with interventions (mirror view due to the software input rules) 


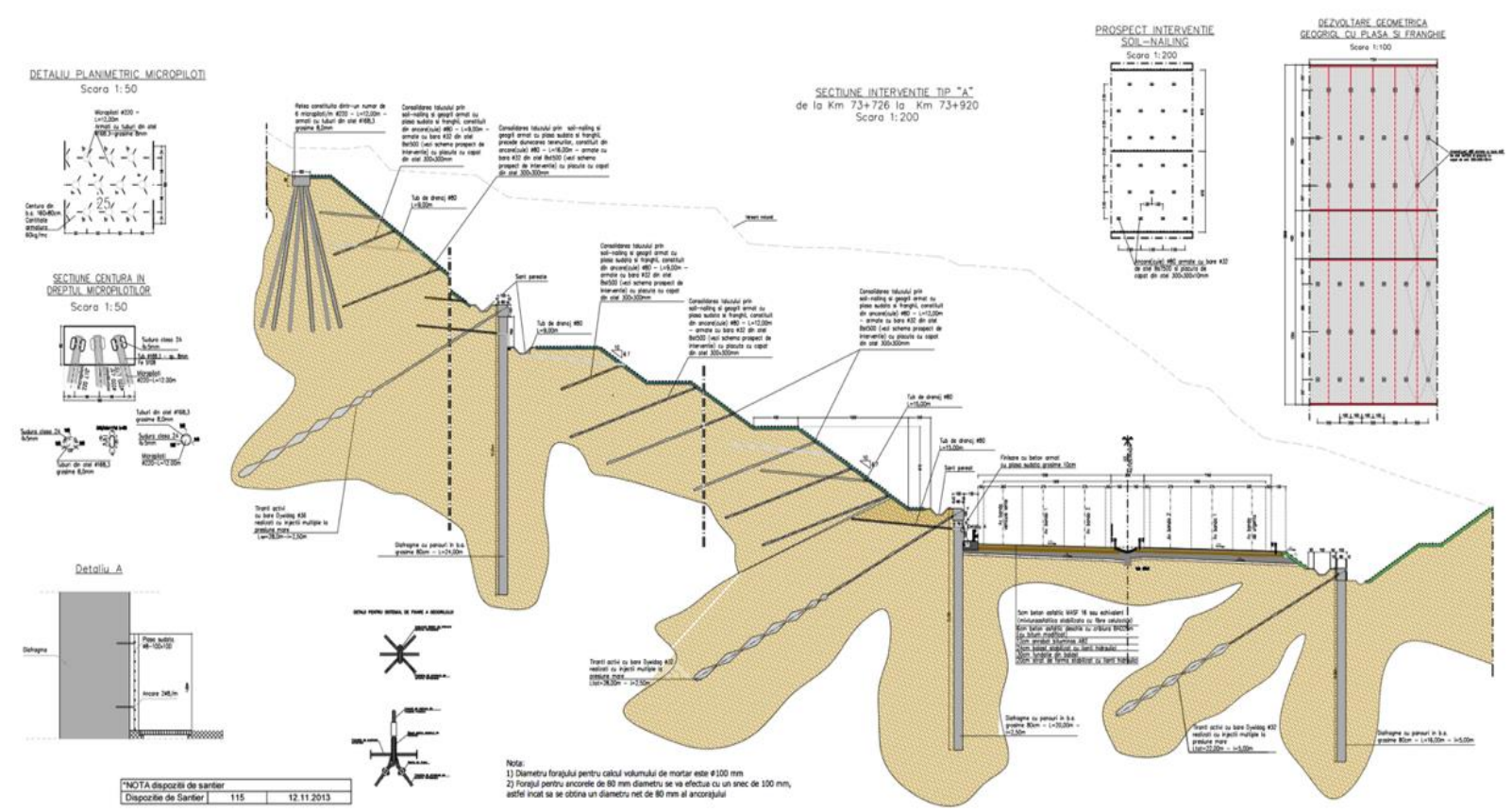

Figure 9. Sketch of the interventions along the new design section (Diaphragm walls, soil nailing, micropiles and drainage system)

The integrated solution proposed is constituted by the following (Figure 9):

- Protection structures of the upper part of the slope, not involved in the landslides;

- Linear retaining structures parallel to the motorway route, defined by three lines of diaphragm walls anchored, distributed in the area with two lines upstream the motorway, one line downstream of it;

- Widespread consolidation, as technical soil-nailing;

- Multilevel complex drainage system, structured by principal and secondary system of channels for the surface water and sub-horizontal drainage pipes for the subsoil water;

- Surface erosion protection, shaped by steel ropes, steel double twist wire mesh and three-dimensional polymeric geomat layer.

\subsection{Protection structures of the upper part of the slope}

The defense of the area not affected by landslides is entrusted to a grid of tilted micropiles, connected by a concrete curb. The tilted micropiles have a length of $12.0 \mathrm{~m}$, a drill diameter of $220 \mathrm{~mm}$ and are reinforced with a steel pipe $\phi 168.3 \mathrm{~mm}-8 \mathrm{~mm}$ thick. The concrete curb has dimensions of $1.60 \mathrm{~m} \times 0.80 \mathrm{~m}$, 
and, for a longitudinal extension of about $150 \mathrm{~m}$, it connects 6 micropiles per meter.

\subsection{Continuous retaining structures - Diaphragm walls with anchorages}

The continuous retaining structures are constituted by three alignments of reinforced concrete $80 \mathrm{~cm}$-thick, the first two are located in the upstream part of the motorway route and the third directly downstream of the latter. Starting from the upper part, the three alignments are $24.0 \mathrm{~m}, 20.0 \mathrm{~m}$ and $16.0 \mathrm{~m}$ deep and they have a longitudinal extension equal to 200,330 and $345 \mathrm{~m}$, respectively. It is important to note that, given the magnitude of the thrust acting on the alignment of the valley, the latter is made up of panels with widths of spacing of $2.5 \mathrm{~m}$ and $5.0 \mathrm{~m}$; the panels of the upstream alignments have a spacing equal to their width. All the diaphragms alignments are also anchored in the lead by means of active anchorages of Dywidag steel bars, achieved by multiple and repeated injections of cement mortar in $140 \mathrm{~mm}$ drillings of $28.0 \mathrm{~m}$ length. The spacing of the anchorages is the same as the diaphragm panels $(2.50 \mathrm{~m}$ upstream, $5.00 \mathrm{~m}$ downstream).

\subsection{Widespread surface consolidation - Soil nailing}

The final transversal shape consists of $2: 3$ slopes, spaced out by $4.0 \mathrm{~m}$ horizontal banks each $6.0 \mathrm{~m}$ in height. In order to ensure the needed requirements of local stability and the provision of a widespread consolidation of the most superficial layer of the excavation profile, it was executed an intervention of soil-nailing. It consists of nails in steel bars of a length between 6.0 and $15.0 \mathrm{~m}$, spaced according to a staggered mesh of $2.0 \mathrm{~m} \mathrm{x} 4.0 \mathrm{~m}$. Each nail is a $32 \mathrm{~mm}$ steel bar BsT500, connected to the ground by injection of cement mortar in a perforation of $80 \mathrm{~mm}$ in diameter. The bolted mesh is reinforced by a mesh of steel wire double twisted and steel ropes.

\subsection{Complex drainage system}

Given the marked influence of water on the mechanical behaviour of Sibiu clays, the interventions set of were equipped with a complex system of drainage and control of the surface runoff and filtration waters. The drainage system is constituted by channels warping, arranged according to the direction of natural slope parallel to the road axis and by a further channel of crowning along the perimeter of the entire area subject to intervention. A sub-channels 
warping was coupled to main channels, in order to connect the main channels along the upstream-downstream direction of the slope. Both the main and secondary channels are made of reinforced concrete, precast or cast on site according to the lines to be drained. Regarding the filtration water, it has been arranged a dense mesh of sub-horizontal drains, consisting of micro-slotted pipes of $80 \mathrm{~mm}$ diameter and a $15.0 \mathrm{~m}$ length.

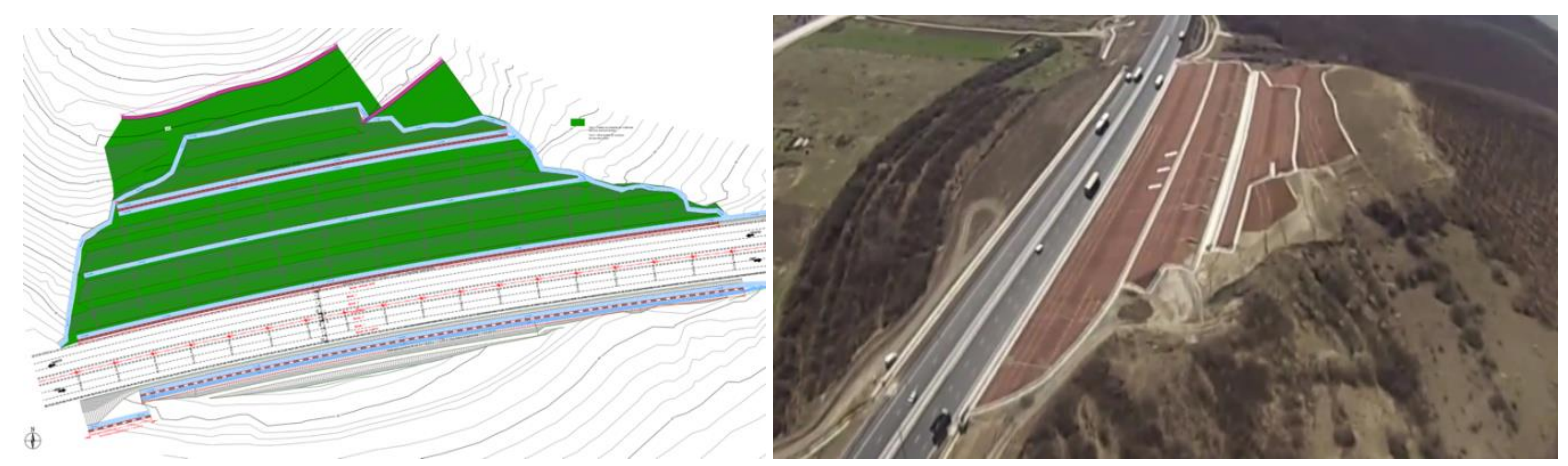

Figure 10. Design plan of the area and aerial view of the intervention completed

\section{GENERAL CONCLUSIONS}

The case presented is an effective example of consolidation of a slope in a precarious state of equilibrium by overlapping different intervention techniques. The set of actions involved on site allowed the reshaping of the hill according to side slopes greater than natural, already at the limit of equilibrium. The extensive geognostic investigations integrative allowed the detailed definition of instabilities encountered, both previous and current genesis, and the accurate definition of the various intervention techniques operated by the contractor Astaldi. The latter, monitored to date by inclinometers on site, allowed the safe prosecution of the work and the opening of the highway branch to traffic.

\section{REFERENCES}

[1]. APAT, "Fenomeni di dissesto geologico-idraulico sui versanti", Manuali e linee guida, 39/2006, 2006, pp.177

[2]. G. Calabresi, "Introduzione al comportamento meccanico dei terreni coesivi", Conferenza di Geotecnica di Torino XI Ciclo "Parametri di progetto da prove in situ”, Atti, 1983, pp.24

[3]. A. Chirică and I. Stănculescu, "Some aspects concerning the macro-structured soils of Romania”, Proc. of XIII ICSMFE, New Delhi, Vol.I, 1994 


\section{ROMANIAN JOURNAL \\ OF TRANSPORT INFRASTRUCTURE}

Anton Chirică, Andrea Danese, Rosario Russo, Lorenzo Sabini Major landslides stabilization on Orăştie-Sibiu motorway

[4]. A. Chirică, "Expertiză tehnică asupra fenomenelor de instabilitate din zona A, cuprinsă între $\mathrm{km} 73+735$ şi $\mathrm{km} 74+020$ şi respectiv, din zona B, situată la km 72+242, lot 4, autostrada Orăştie-Sibiu”, 2013, 35 p.

[5]. Comitetul de stat al geologiei - Institutul geologic, "Harta geologică scara 1:200.000 F. 26 Orăştie L-34" - XXIV, 1968

[6]. Comitetul de stat al geologiei - Institutul geologic, "Harta geologică scara 1:200.000 - F. 27 Sibiu L-35” - XIX, 1968

[7]. A. Constantinescu et al., "Analysis of a progressive failure in Panonian clays", Proc. ECSMFE, Brighton, 1979

[8]. A. Evangelista, "Sistemi drenanti per la stabilizzazione dei versanti - Tipi e schemi di funzionamento", CISM 2007, Interventi di stabilizzazione dei pendii, 1997, pp.400411

[9]. F. Esu, “Controllo dell'efficacia nel tempo degli interventi di stabilizzazione”, CISM 2007, Interventi di stabilizzazione dei pendii, 1997, pp.511-526

[10]. D. Peila, "Chiodature nei terreni: caratterizzazione tecnica e metodi di dimensionamento", Bollettino della Associazione Mineraria Subalpina, Anno XXV, n. 4 , 1988, pp 505-520

[11]. Y.C. Tan and C.M. Chow, "Slope Stabilization Using Soil Nails: Design Assumptions and Construction Realities", 2004 